\title{
PENERAPAN METODE THERAPEUTIC ARCHITECTURE PADA HUNIAN PRODUKTIF \& RUANG KOMUNAL BAGI PENDUDUK LANJUT USIA
}

\author{
Shienia ${ }^{1)}$ dan Suryono Herlambang ${ }^{2)}$ \\ 1)Program Studi S1 Arsitektur, Fakultas Teknik, Universitas Tarumanagara, shieniagunawan99@gmail.com \\ 2) Program Studi S1 PWK, Fakultas Teknik, Universitas Tarumanagara, s.herlambang@gmail.com
}

Masuk: 04-07-2021, revisi: 14-08-2021, diterima untuk diterbitkan: 23-10-2021

\begin{abstract}
Abstrak
Sejak Bulan Desember 2019, penyebaran pandemic akibat virus Corona, yang juga dikenal sebagai Coronavirus (COVID-19) menyerang hampir satu dunia. Berbagai aspek kehidupan penduduk global terdampak secara signifikan dengan adanya persebaran virtus Pandemi ini. Berbagai negara menanggapi ancaman penyakit ini, terutama karena pandemi menyerang semua kelompok usia, terutama pada kelompok umur lanjut usia. Penduduk lansia menghadapi risiko yang signifikan terkena penyakit virus corona ini, apalagi jika mereka mengalami gangguan kesehatan yang diiringi dengan penurunan kondisi fisiologis. WHO mencatat lebih dari 95\% kematian yang diakibatkan virus corona terjadi kepada penduduk kelompok usia lebih dari 60 tahun. 8 dari 10 kematian terjadi pada individu dengan komorbiditas, khususnya mereka dengan penyakit kardiovaskular, hipertensi, diabeter, juga berbagai kondisi kronis lainnya. Sangat penting bagi negara untuk memberikan respon komprehensif terhadap pandemic ini, dengan mendukut penduduk lansia, keluarga, dan pengasuhnya. Pada kondisi ini, lanjut usia memerlukan adanya perlindungan, dan akses terhadap makanan bergizi, ketersediaan kebutuhan dasar, uang, obat-obatan untuk mendukung kesehatan fisik, dan perawatan. Tujuan dari penelitian ini adalah mencari data dan analisa spesifik sebagai landasan desain Hunian Produktif bagi Lanjut usia dengan metode desain Therapeautic Architecture. Diharapkan dengan penelitian ini mampu menjabarkan dan membuktikan aspek alam sebagai bagian dari rancangan lingkungan binaan untuk mendukung proses penyembuhan khususnya pada hunian produktif bagi penduduk kelompok usia lanjut.
\end{abstract}

Kata kunci: Covid-19; Lanjut Usia; Hunian Komunitas; Populasi Tua; Binaan Lingkungan Penyembuhan

\begin{abstract}
Since December 2019, world has been infected the spread of pandemic by Coronavirus or also we known as COVID-19. This pandemic has been effecting the global population drastically, and also various aspects of human life. There's so many countries is being faced the threat of this disease, especially for elderly citizens. The elderly population has higher risk of being infected to this disease more than any age group, especially for they who has any health problems and degenerative physiological conditions. WHO noted more than $95 \%$ mortality caused by coronavirus threat ages population. 8 out of 10 deaths occur in individuals with comorbidities, particularly those with cardiovascular disease, hypertension, diabetes, as well as various other chronic conditions. It is imperative for countries to provide a comprehensive response to this pandemic, supporting the elderly population, their families and their care givers. In this condition, the elderly need protection, and access to nutritious food, availability of basic necessities, money, medicine to support their physical health, and care. The purpose of this research is to find specific data and analysis as the basis for the design of productive housing for the elderly using the Therapeautic Architecture design method. Writer also hoping, this research will be able to describe and prove aspects of nature as part of the design to built environment that support the healing process, especially in productive housing for the elderly population.
\end{abstract}

Keywords: Covid-19; Elderly; Community Housing; Ageing Population; Therapeutic Architecture 


\section{PENDAHULUAN}

\section{Periode Ageing Population}

Lanskap demografis kota kita berubah dengan waktu cepat, seiring pertumbuhan kota dan pertambahan usia penduduk. Aging population merupakan fenomena yang terjadi disetiap negara dimana penduduk lanjut usia lebih banyak dari usia produktif. Pandemi COVID-19 menyerang penduduk usia lanjut sebagai kelompok usia paling rentan terpapar. pada kondisi ini, penduduk lansia memiliki kebutuhan atas fasilitas yang memberi perlindungan dan perhatian khusus terhadap kualitas hidup yang menurun diakibatkan fisik dan psikis yang rentan terserang virus. Konsep arsitektur terapeutik merupakan sebuah metode perancangan arsitektur dimana mendukung binaan lingkungan yang mendorong percepatan proses penyembuhan manusia didalamnya. Aspek-aspek arsitektur yang disebutkan di atas contohnya adalah warna, bentuk, serta hubungan manusia dengan alam.

Beberapa penelitian menunjunukan bahwa manusia memiliki hasrat untuk terhubung dengan alam dan integrasi lingkungan alam ke dalam ruang manusia tinggal dapat meningkatkan efektifitas proses penyembuhan dan tentunya terhadap psikologis manusia. Konsep terapeutik ini biasa diterapkan pada lingkungan binaan yang terdapat aktifitas kesehatan seperti rumah sakit, klinik, maupun pusat rehabilitasi. Penelitian oleh Roger Ulrich menyimpulkan bahwa pemulihan pasien setelah operasi memiliki proses penyembuhan yang lebih efektif ketika mereka memiliki jendela di kamar yang menghadap alam. Penelitian lainnya menunjukan bahwa tekanan darah dan aktivitas jantung yang disebabkan oleh stres dapat menurun jika pasien dihubungkan dengan alam langsung, hal ini dikarenakan alam terbukti mampu mengalihkan manusia dari pikiran mereka dan masalah yang mengganggu pikiran. Selain lingkungan alam, integrasi sosial juga dinilai mampu memberikan kontribusi yang signifikan dalam meningkatkan dukungan sosial bagi pasien, keluarga dan caregivers.

\section{Latar Belakang}

Lanskap demografis yang berubah dengan cepat, diiringi dengan pertumbuhan kota dan pertambahan usia penduduk salah satu menjadi dasar terjadinya Aging Population. Hal ini menunjukan populasi lansia bertumbuh lebih cepat dari rasio kelahiran. Peningkatan penduduk lansia menimbulkan konsekuensi yang kompleks. Satu hal yang paling utama adalah kestabilan finansial penduduk lansia. Tidak banyak lansia yang memiliki jaminan pensiun atau telah mempersiapkan finansial secara matang untuk kehidupan di hari tua. Sehingga tidak dapat dipungkiri bahwa orang tua (lansia) secara ekonomi harus bergantung pada anaknya. Hal ini menjadikan penduduk usia produktif memiliki beban tanggungan yang besar yaitu diri sendiri, keluarga inti, dan orang tua. Transisi demografi yang mengubah struktur penduduk menjadi ageing population juga diiringi dengan transisi epidemiologi dari penyakit menular menjadi penyakin degenerative ( menurunya fungsi organ).

\section{Rumusan Permasalahan}

Pandemi COVID-19 yang terjadi sepanjang tahun 2020 juga menjadi salah satu tantangan yang harus dihadapi oleh lansia. WHO menyatakan bahwa lansia merupakan kelompok usia paling rentan terpapar COVID-19. kerentanan pada lansia terjadi karena melemahnya fungsi imun serta adanya penyakit degenerative seperti jantung, hipertensi, dan diabetes (LIPI, 2020). Dari data WHO, di Indonesia berdasarkan data bulan Juni 2020, persentase kematian pada kelompok lansia sebesar 43,60\% dimana angka ini merupakan yang tertinggi dibanding kelompok umur lainnya.

Pada kondisi ini, penduduk lansia memerlukan perlindungan dan perhatian untuk meningkatkan kualitas hidupnya, terutama secara fisik dan psikis yang lebih mudah stress. Terjadinya peningkatan jumlah lansia, selain menjadi tantangan, juga dapat memberikan kontribusi yang baik bagi negara apabila lansia berada dalam keadaan sehatm mandiri, aktif dan produktif. Sehingga terancamnya kualitas hidup penduduk lansia mampu mengubah bentuk demografis ke arah yang destruktif. 


\section{Tujuan}

Berdasarkan latar belakang dan identifikasi masalah, tujuan dari perancangan ini adalah memberikan perlindungan serta memberi wadah untuk aktifitas produktif bagi penduduk kelompok usia lanjut usia sebagai respon komprehensif terhadap fenomena aging population yang diiringi dengan pandemic COVID-19. Diharapkan, dengan proyek ini mampu meningkatkan kualitas hidup khususnya penduduk kelompok usia lanjut.

\section{KAJIAN LITERATUR}

\section{Lansia}

Definisi menurut Notoatmojo, Lanjut Usia adalah tahapan normal sebuah perkembangan yang pasti dialami oleh setiap individu dan merupakan sebuah kenyataan yang tidak dapat dihindari. Batasan lanjut usia dapat ditinjau melalui berbagai aspek biologi, sosial, dan batasan usia, yaitu:

\section{Aspek Biologi}

Kelompok lanjut usia ditinjau dari aspek biologi, merupakan seorang/individu yang sudah melewati proses penuaan atau daya tahan fisik yang menurun yang ditandai dengan tubuh semakin rentan terhadap berbagai serangan penyakit yang bisa menyebabkan kematian. Hal ini terjadi seiring meningkatnya usia yang menyebabkan terjadi perubahan dalam struktur dan fungsi sel, jaringan, serta sistem organ.

\section{Aspek Sosial}

Ditinjau dari sudut pandang sosial, kelompok lanjut usia merupakan kelompok sosial tersendiri. Bagi masyarakat penduduk Asia, lansia memiliki kelas sosial yang tinggi, sebagai kelompok usia yang harus dihormati oleh masyarakat.

\section{Aspek Umur}

a) Definisi Lanjut Usia menurut Kamus Besar Bahasa Indonesia, adalah proses masa tua dalam perkembangan individu dengan batas usia 60 tahun ke atas.

b) Menurut Second World Assembly on Ageing (SWAA) di Madrid (8-12 April 2002) yang menghasilkan Rencana Aksi Internasional Lanjut Usia (Madrid International Plan of Action on Ageing), seseorang disebut sebagai lansia jika berumur 60 tahun ke atas (di negara berkembang) atau 65 tahun ke atas di negara maju.

Klasifikasi penggolongan Lansia menurut Schroeder dibagi berdasarkan ketergantungannya menjadi 3 golongan, yaitu:

\section{Lanjut usia mandiri (independent elderly)}

Lansia dengan keadaan fisik sehat tanpa disabilitas emosinal seperti tidak murung, tidak mudah curiga, depresif, dan rewel. dengan begitu, masih sanggup melakukan aktivitas rutin dengan tidak bergantung pada bantuan orang lain atau paling tidak hanya ketergantungan sosial.

2. Lanjut usia semi mandiri (semi independent elderly)

Lanjut usia dengan golongan ini antara lain adalah lansia dengan penyakit tertentu dan lansia yang mengalami fungsi panca indera yang menurun cukup parah serta memiliki ketergantungan domestik.

\section{Lanjut usia tidak mandiri (dependent elderly)}

Lanjut usia dengan golongan tidak mandiri adalah lansia dengan penyakit tertantu secara serius atau dengan disabilitas emosional dan social yang digolongkan cukup parah diikuti dengan ketergantungan personal. 


\section{Perubahan pada Kaum Lansia}

\section{A. Aspek Fisik Menurut Hurlock (1996)}

dalam bukunya yang berjudul "psikologi perkembangan: suatu pendekatan sepanjang rentang kehidupan" memaparkan perubahan fisik yang terjadi pada golongan lanjut usia (Hurlock 1996). Perubahan fisik yang terjadi meliputi sebagai berikut:

1. Perubahan penampilan, perubahan yang terjadi adalah:

a) Bagian kepala: hidung menjulur lemas. Bentuk mulut berubah karena hilangnya gigi, mata kelihatan pudar.

b) Bagian tubuh: bahu membungkuk dan tampak mengecil, perut membesar dan membuncit, penimbunan lemsk di perut dan panggul serta kulit mengendur.

c) Persendian

\section{Perubahan bagian dalam tubuh}

Perubahan yang terjadi dalam tulang mengapur dan mudah retak (keropos), berkurangnya berat otak dan bilik jantung yang semakin lebar.

\section{Perubahan fisiologis}

Perubahan yang terjadi adalah pengaturan suhu tubuh menjadi sulit, meningkatnya tekanan darah, penurunan jumlah waktu tidur, dan kemampuan bekerja menurun.

4. Perubahan pada panca indera

a) Menurunnya fungsi indera penglihatan guna melihat obyek pada cahaya penerangan yang kurang atau rendah, menurunnya sensitivitas penglihatan terhadap warna dan umumnya menderita presbiopi (cacat mata tua)

b) Menurunnya kepekaan fungsi indera peraba karena kulit semakin kering dan keras.

c) Menurunnya fungsi indera perasa.

d) Menghilangnya kemampuan untuk mendengar bunyi dengan kekuatan tinggi dan rendah.

e) Menurunnya ketajaman indera penciuman

f) Menurunya kemampuan menahan rasa sakit pada setiap bagian tubuh.

\section{Perubahan seksual}

6. Perubahan kemampuan motoric

a. Kekuatan khususnya kelenturan otot tangan bagian depan serta otot yang guna menopang tegaknya tubuh, selain itu golongan lansia lebih mudah lelah dan memerlukan jumlah istirahat lebih banyak ketimbang kelompok usia lebih muda

b. Kecepatan motorik

c. Belajar keterampilan baru

7. Kelakuan Cenderung kagok dan canggung sehingga sering menumpahkan dan kehilangan genggamannya. 


\section{B. Aspek Psikologi}

1. Kognisi daya ingat yang menurun, seiring dengan menurunnya kepintaran, kapabilitas, keahlian atau intelegensi dalam memproses informasi.

\section{Afeksi}

Dalam kehidupan bermasyarakat, manusia tidak akan bisa jauh dari kehidupan sosial antara manusia satu dengan manusia yang lain saling membutuhkan. Lansia membutuhkan lebih banyak perhatian dari orang-orang disekelilingnya.

Terdapat 3 aspek hubungan sosial pada lansia, yaitu hubungan persahabatan (friendship), dukungan sosial (social support), dan integerasi sosail (social integeration) (Andesty and Shyahrul 2017)

\section{Persahabatan}

Cenderung lansia merupakan seseorang yang sudah ditinggal orang orang terdekatnya, sehingga membuat lansia bersifat lebih tertutup terhadap sosial.

\section{Dukungan sosial}

Dukungan sosial adalah sebuah sarana relatif yang mampu memberikan bantuan terhadap individu untuk mengatasi masalahnya, juga dapat meningkatkan kesehatan baik secara fisik dan psikis pada kelompok lanjut usia.

\section{Integerasi sosial}

Menurut Arri Handayani, pada tulisannya yang berjudul "Kesepian pada Lansia" pada sebuah majalah psikologi, dikatakan kondisi seorang lansia yang mengalami kesepian dan rasa terbatasnya terhadap sosial dapat menjadi faktor yang beresiko yang mengancam kesehatan individu lanjut usia. kondisi dimana lansia merasa kesepian dapat terjadi dikarenakan ditinggalkan orang yang dikasihi seperti pasangan, kepergian buah hati, bahkan sampai merasa dirinya tidak berguna atau tidak berharga.

\section{Permasalahan Lansia (Mangoenprasodjo 2005)}

a) Kondisi mental:secara psikologis, umumnya pada usia lanjut terdapat penurunan baik secara kognitif maupun secara psikomotorik. Contohnya, penurunan pemahaman dalam menerima permasalahan dalam kelambanan bertindak.

b) Keterasingan (loneliness): terjadi penurunan kemampuan pada individu dalam mendengar, melihat, dan aktivitas lainnya sehingga merasa tersisih dari masyarakat.

c) Post Power Syndrome: kondisi ini terjadi pada seseorang yang smeula memiliki jabatan pada masa aktif bekerja. Setelah berhenti bekerja, orang tersebut merasa ada sesuatu yang hilang dalam hidupnya.

d) masalah penyakit: selai karena proses fisiologis yang menuju ke arah degeneratif, juga banyak ditemukan gangguan pada manusia lanjut usia, antara lain: infeksi, jantung dan pembulu darah, penyakit metabolik, osteoporsis, kurang gizi, penggunaan obat dan alkohol, penyakit syaraf (stroke), serta gangguan jiwa terutama depresi dan kecemasan.

Permasalahan yang dialami lansia memberikan kesimpulan bahwa dengan keterbatasan yang di alami maka harus diciptakan suatu lingkungan yang dapat membantu aktivitas lansia dengan keterbatasannya. 
Kebutuhan Hidup Lansia (Maslow 2021)

a) Kebutuhan Fisik (Physiological needs) merupakan kebutuhan yang sangat primer, berupa kebutuhan fisik atau biologis seperti pangan, sandang, papan yang harus mutlak dipenuhi untuk memelihara homeostatis biologis dan kelangsungan hidup bagi setiap manusia.

b) Kebutuhan ketentraman (Safety needs) Merupakan kebutuhan untuk memenuhi rasa aman, tentram dan baik secara lahiriah maupun batiniah seperti kebutuhan terhadap jaminan di hari tua, kebebasan, kemandirian, dan lainnya.

c) Kebutuhan Sosial (Social needs) Merupakan kebutuhan untuk memenuhi bermasyarakat atau berkomunikasi dengan mahluk social lainnya seperti komunitas, organisasi, teman profesi, kesenian, olahraga, hobi dan lainnya.

d) Kebutuhan harga diri (Esteem needs) adalah kebutuhan memenuhi rasa ingin diakui keberadaanya, kebutuhan akan harga diri, dimana merupakan proses evaluasi yang ditunjukan individu pada dirinya sendiri, serta proses penerimaan individu terhadap dirinya sebagai seorang individu.

e) Kebutuhan aktualisasi diri (Self actualization needs) adalah rasa ingin mengungkapkan kemampuan baik secara fisik, rohani maupun daya pikir berdasarkan pengalamanya masing-masing, semangat hidup, serta peran dalam kehidupanya sendiri dan orang lain.

\section{Prinsip Perancangan Hunian khusus Lansia}

Dalam artikel "Pynos dan Regnier" (Reginer 1994) tertulis tentang 12 macam prinsip yang diterapkan pada lingkungan dalam fasilitas lansia untuk membantu dalam kegiatakegiatan lansia. Kedua-belas prinsip tersebut dikelompokkan dalam aspek fisiologis dan psikologis, yaitu sebagai berikut:

\section{Aspek Fisiologis}

a. Keselamatan dan keamanan, menyediakan lingkungan yang maampu memberikan kepastian terhadap penggunanya tidak akan mengalami bahaya yang tidak diharapkan. Lansia memiliki penurunan fisik dan panca indera seperti gangguan penglihatan, kesulitan mengatur keseimbangan, kekuatan kaki menopang tubuh, serta persendian yang mengakibatkan lansia lebih rentan jatuh dan cidera. Penurunan kadar kalsium pada tulang juga dapat menyumbang risiko lansia mengalami patah tulang, maka dari itu, permasalahan fisik ini menyebabkan skala terjadinya kecelakaan terhadap lansia cukup tinggi.

b. Signage/orientation/wayfindings, Ketersediaan penunjuk arah pada sebuah lingkungan dapat memberikan kemudahan untuk lansia menemukan dan menggunakan fasilitas yang tersedia. Perasaan tersesat adalah hal yang dapat memicu rasa takut, bingung pada lansia yang lebih lanjut dapat mengurangi rasa percaya dan penghargaan diri lansia, depresi dapat berdampak terhadap penurunan daya tahan tubuh lansia dan berpengaruh langsung terhadap kesehatannya.

c. Aksesibilitas dan fungsi, tata letak dan aksesibilitas merupakan syarat mendasar untuk lingkungan yang fungsional. Aksesibilitas adalah kendala untuk memperoleh dan menggunakan sarana, prasarana dan fasilitas bagi lanjut usia untuk memperlancar mobilitas lanjut usia.

d. Adaptabilitas, yaitu kemampuan untuk menyesuaikan diri dengan lingkuang, lingkungan harus dirancang sesuai dengan pemakainya, termasuk yang menggunakan kursi roda maupun tongkat penyangga. Kamar mandi dan dapur merupakan ruangan dimana aktivitas banyak dilakukan dan keamanan harus menjadi pertimbangan utama.

\section{Aspek Psikologis}

a) Privasi, menyediakan kesempatan bagi lansia untuk mengasingkan diri dan bebas dari gangguan yang tidak dikenal ( Auditory privacy). 
b) Interaksi sosial, merupakan sebuah hubungan social yang dinamis, berupa hubungan antara individu dengan individu lainnya, antara kelompok yang satu dengan kelompok lainnya, maupun antara kelompok dengan individu, mendorong adanya pertukaran informasi, aktivitas rekreasi, berdiskusi dan meningkatkan pertemanan. Interaksi sosial dinilai mampu mengurangi kemungkinan terjadinya depresi dengan cara mendorong serta memberikan kesempatan lansia untuk berbagi pengalaman, masalah, cerita kehidupan sehari-hari mereka.

c) Kemandirian, memberikan peluang untuk lansia melakukan aktivitas sendiri yang dapat menimbulkan kepuasan tersendiri pada lansia.

d) Dorongan/ tantangan, yaitu dimana sebuah lingkungan mampu memberikan dorongan terhadap lansia untuk beraktivitas dengan pola pola visual seperti warna, keanekaragaman ruang dan sebagainya.

e) Aspek panca indera, Rancangan dengan memperhatikan kerja panca indera dapat dimanfaatkan untuk membuat rancangan yang lebih merangsang atau menarik.

f) Estetik/penampilan, suatu rancangan lingkungan yang tampak menarik.

g) Personalisasi, yaitu menciptakan lingkungan yang pribadi dan menandai sebagai milik seorang (mampu membangun sense of belonging)

\section{METODE}

Rumah ramah lansia merupakan wadah bagi lansia dalam pelayanan kesejahteraan para lanjut usia dalam kondisi sehat dan mandiri yang memiliki keluarga namun dititipkan karena ketidak mampuan keluarga untuk merawat manula. Seiring berjalannya waktu rumah ramah lansia ini akan memenuhi kebutuhan hidup para lanjut usia di hari tuanya dalam keadaan tentram 17 lahir dan batin. Tempat ini menjadi tempat menjalani proses penuaannya dengan sehat dan mandiri. Dalam perancangan ini diharapkan mampu menunjang kebutuhan masyarakat terutama bagi para lanjut usia seraya membantu upaya penyeleggaraan pelayanan sosial daerah lewat pengimplementasikan ide-ide arsitektural yang semakin berkembang.

Lansia adalah seseorang yang telah memasuki usia 60 tahun keatas. Lansia merupakan kelompok umur pada manusia yang telah memasuki tahapan akhir dari fase kehidupannya. Kelompok yang dikategorikan lansia ini akan terjadi suatu proses yang disebut Aging Process atau proses penuaan. Proses penuaan adalah siklus kehidupan yang ditandai dengan tahapan- tahapan menurunnya berbagai fungsi organ tubuh, yang ditandai dengan semakin rentannya tubuh terhadap berbagai serangan penyakit yang dapat menyebabkan kematian misalnya pada sistem kardiovaskuler dan pembuluh darah, pernafasan, pencernaan, endokrin dan lain sebagainya. Usia Lanjut merupakan sebuah tahap akhir siklus kehidupan yang menunjukan perkembangan yang normal dan lazim dialami oleh setiap individu.

Batasan lanjut usia dapat ditinjau dari aspek biologi, sosial, dan usia atau batasan usia , yaitu:

- Aspek Biologi,Lansia merupakan seorang/ individu yang sedang menjalani proses penuaan ditandai dengan menurunnya daya tahan fisik dan rentannya tubuh terhadap berbagai serangan penyakit .

- Aspek Sosial,Dari sudut pandang sosial, lansia merupakan kelompok sosial tersendiri.

- Aspek Umur,Dari kedua aspek di atas, pendekatan umur adalah yang ,paling memungkinkan untuk mendefinisikan lansia secara tepat

Secara umum, arsitektur sebagai media behaviour modifier diharapkan membawa dampak positif untuk proses Kesehatan jiwa bila diterapkan pada bangunan atau lingkungan binaan. Konsep therapeutic architecture dapat diterapkan pada healthcare building ataupun lingkungan binaan yang terdapat aktivitas pengobatan di dalamnya. Dalam konsepnya, aspek - aspek arsitektur dimanipulasi sedemikian rupa untuk mempercepat proses penyembuhan. 


\section{DISKUSI DAN HASIL}

Kota Jakarta Utara berpotensi memberikan fasilitas hunian elderly yang layak dikarenakan kota Jakarta merupakan jantung pusat kegiatan serta memiliki kepadatan penduduk yang tinggi dari banyaknya perpindahan penduduk, angka kelahiran, sampai lansia yang meningkat. Hunian dapat membantu keluarga muda memenuhi kebutuhan orang tua mereka, baik dari segi fasilitas, kesehatan, dan perawatan, interaksi sosial, serta kenyamanan.

Tapak merupakan tanah kosong yang terletak di sebuah area perumahan di Jakarta Utara, tepatnya di Jl. Danau Utara, Papanggo, Kel. Sunter Jaya, Jakarta Utara. Tapak memiliki potensi view yang sangat tinggi karena terletak di sebrang Danau Cincin serta Hutan Kota

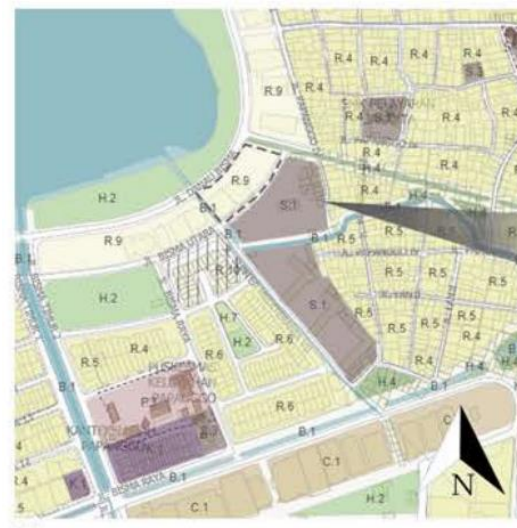

Informasi Rencana Kota

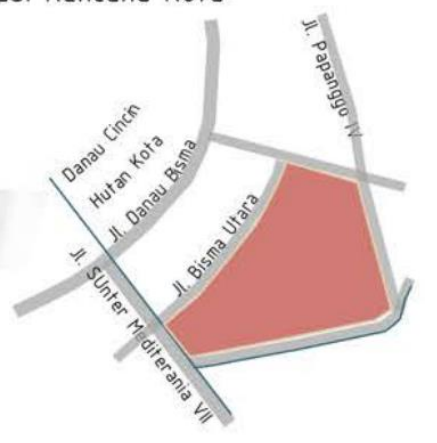

$\begin{array}{ll}\text { Sub Zona } & : \text { Layanan Sosial } \\ \text { PSL } & : P \\ \text { KDB } & : 30 \\ \text { KLB } & : 2 \\ \text { KB } & : 4 \\ \text { KDH } & : 45 \\ \text { KTB } & : 0 \\ \text { Tipe } & : T\end{array}$

Gambar 2. 1 Eksisting Tapak

ssumber : Jakarta Satu

Tapak memiliki luas lahan sebesar $10.369 \mathrm{~m}^{2}$ dengan KDB 30, KLB 2, KB 4, KDH 45, dan KTB 0 dan dengan zonasi Layanan Sosial.

Desain bangunan berangkat dari kebutuhan user didalamnya, yaitu penduduk lanjut usia. Masyarakat Lansia tentunya membutuhkan fasilitas yang membantu mereka untuk meningkatkan aktivitasnya baik dari segi sosial, jasmani, dan rohani. Penduduk Lanjut Usia dibagi menjadi 2 kategori yaitu Lansia potensial dan lansia non-potensial. Lansia potensial adalah lansia yang masih dikatakan mampu melakukan pekerjaan dan kegiatan yang bisa menghasilkan produk baik barang maupun jasa, termasuk lansia yang baru saja mengalami pensiun. Menurut Parnes dan Nessel (Corsini, 1987) mengatakan bahwa pensiun adalah suatu kondisi di mana individu tersebut telah berhenti bekerja pada suatu pekerjaan yang sebelumnya dilakukan. Sedangkan, yang kedua adalah Lansia tidak potensial, yaitu Lansia yang sudah tidak memiliki kemampuan untuk menghasilkan barang dan jasa sehingga hidupnya bergantung dengan orang lain dan dikatakan tidak berdaya, dikarenakan lansia sudah tidak lagi produktif, dengan begitu mereka membutuhkan perhatian khusus termasuk area yang mempermudah mereka dalam melakukan berbagai aktifitas yang mampu meningkatkan kualitas hidupnya baik secara jasmani dan rohani.

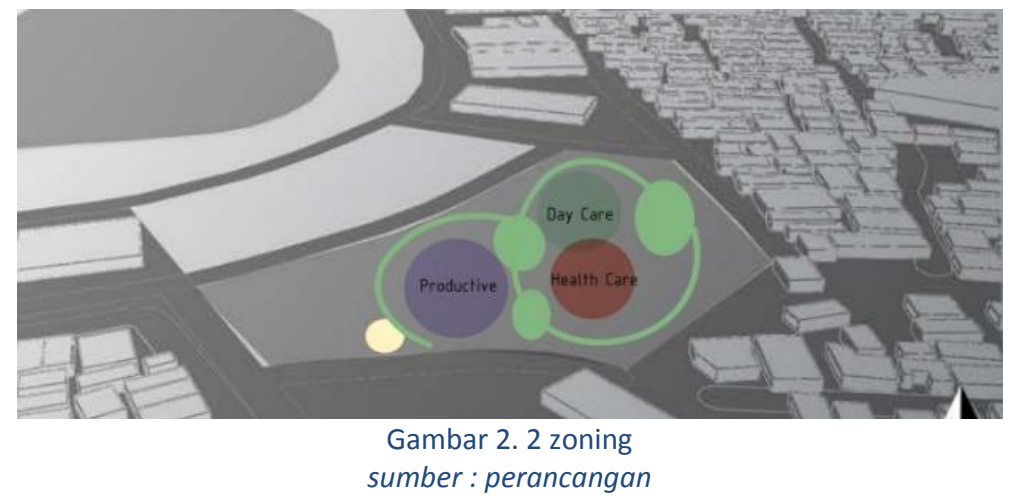


Transformasi masa merupakan hasil dari analisa tapak yang dipadukan dengan analisa zoning. Zoning memiliki konsep masing-masing masa yang dikelilingi memiliki akses baik secara visual dan terkoneksi langsung dengan area hijau. Bangunan juga menghadap langsung ke taman kosong yang dirancang sebagai taman publik khusus lansia sekaligus menjadi akses langsung dari tapak ke Danau Cincin.

Konsep yang digunakan adalah sederhana dengan menghubungkan bangunan terhadap neighborhood dan dengan alam. Konsep digunakan dengan dasar kebutuhan user akan sosialisasi (linked to neighborhood) dan hubungan manusia dengan alam sebagai jembatan yang membantu proses penyembuhan manusia. Data mengatakan alam mampu mengurangi stres pada manusia, serta meningkatkan ketenangan pada pikiran manusia sehingga hal ini akan mengarah kepada kualitas tidur yang baik. Maka dari itu konsep menghubungkan bangunan dengan alam dengan cara membuka akses langsung terhadap taman didepan tapak untuk ruang hijau khusus lansia yang sekaligus menjadi penghubung antara bangunan dengan Danau Cincin dan Hutan Kota. Selain itu terdapat taman publik di dalam tapak yang menghubungkan lansia dengan publik untuk meningkatkan rasa sosial.

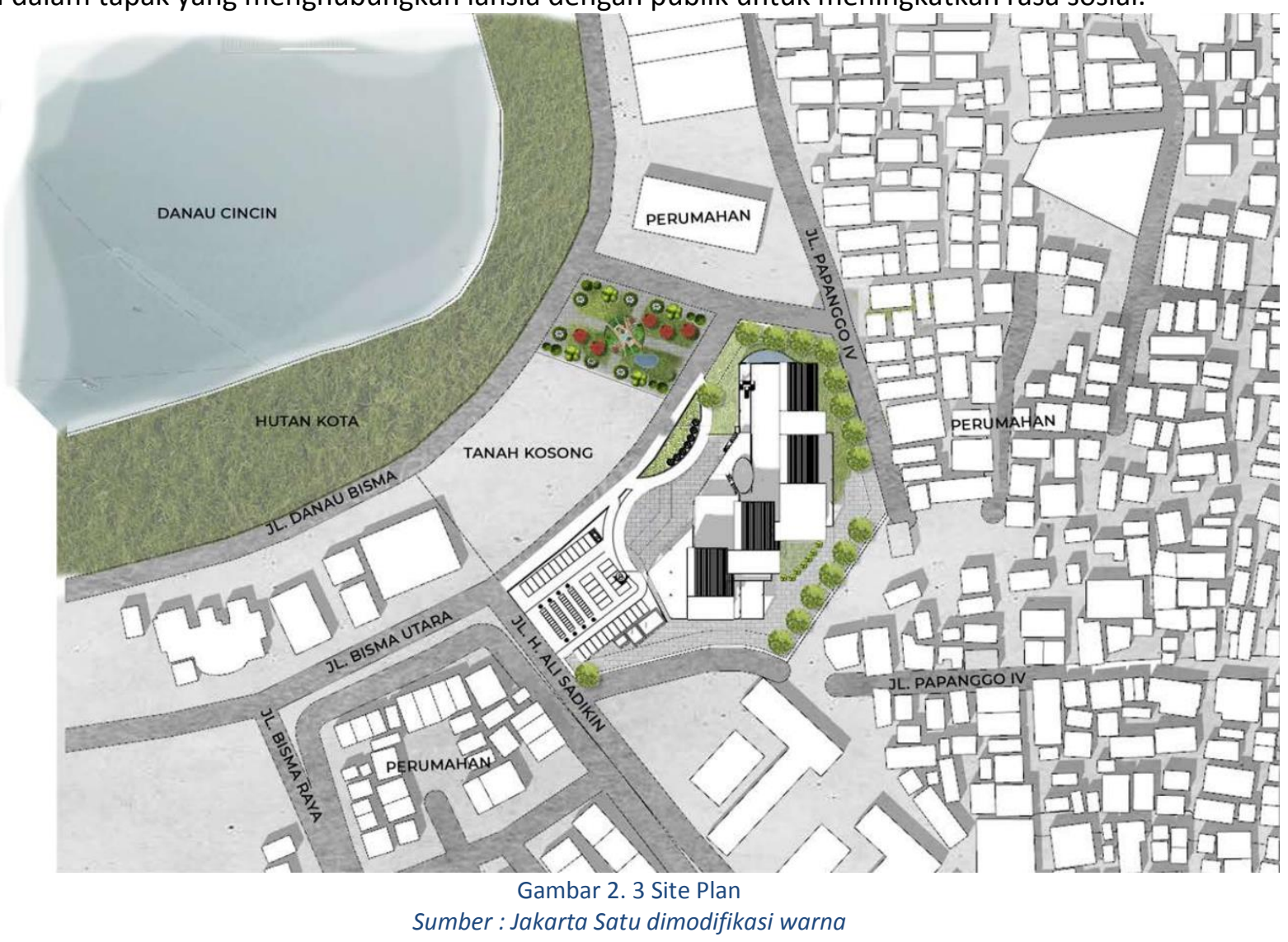

Sifat dari perancangan hunian ini adalah menciptakan lingkungan hidup compact berbasis lanjut usia dengan menyediakan wadah bagi lansia untuk produktif yang dipadukan dengan hunian tinggal assisted living, dan layanan kesehatan, serta ruang komunitas sehingga diharapkan desain mampu memberikan dunia kecil yang aman bagi lansia untuk meningkatkan kualitas hidupnya. Tipe Hunian didalamny ditujukan pada penghuni tetap dan penghuni tidak tetap. Penghuni tetap adalah user yang menetap pada hunian didalamnya dan menggunakan fasilitas assisted living, sedangkan penghuni non tetap adalah penghuni yang menggunakan fasilitas harian seperti area daycare dan ruang komunal bagi Lansia untuk menjaga produktifitas. Sarana ini ditujukan kepada Lansia potensial diadakan guna lansia menyalurkan hobi, sosialisasi serta tetap aktif. 


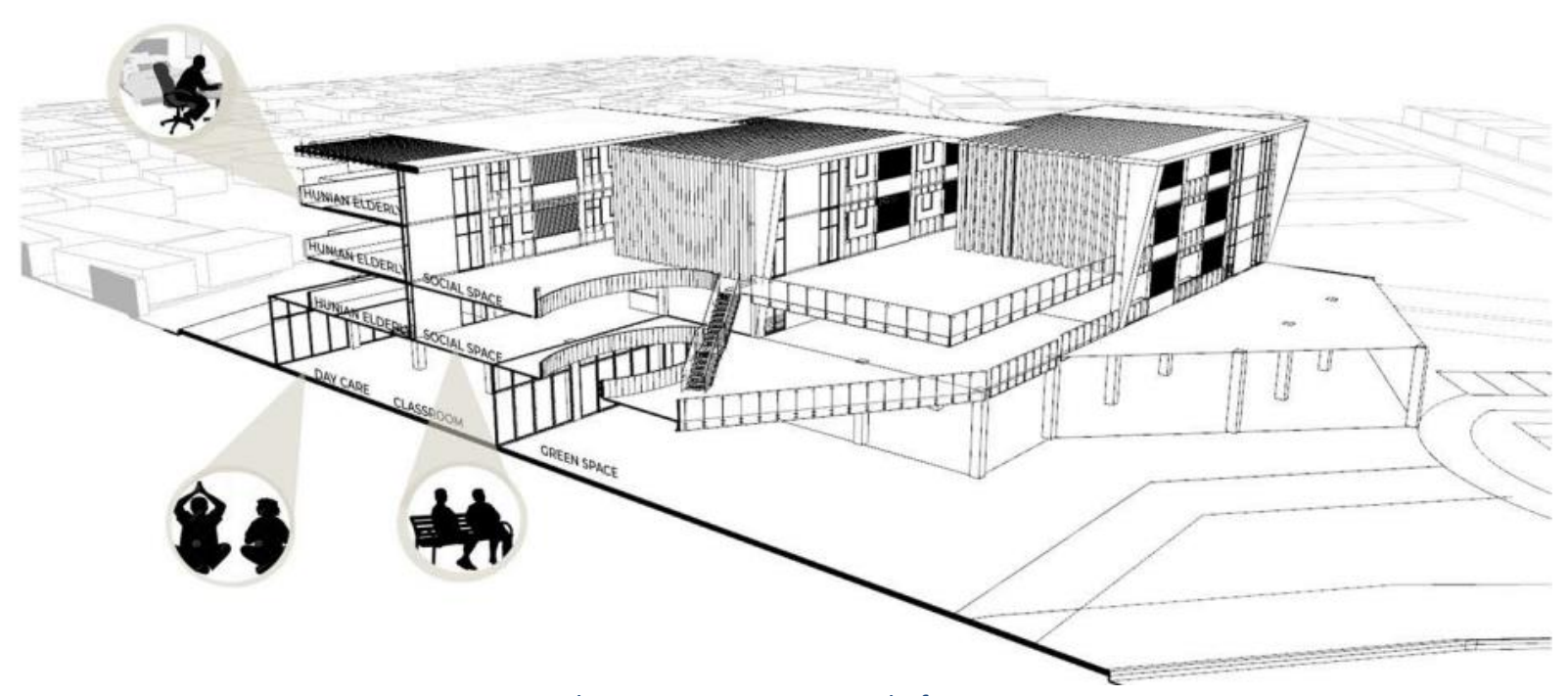

Gambar 2. 4 Potongan Perspektif Bangunan

sumber : Gambar Perancangan

Analisis pengolahan tapak terdiri dari analisis pencapaian, kebisingan, serta analisis matahari dan angin yang menghasilkan zonasi ruang pada bangunan. Analisis pencapaian menentukan main entrance tapak yaitu dari muka tapak yang berorientasi terhadap Danau Cincin. Dan Side Entrance digunakan untuk keperluan Service. Konsep Therapeutic architecture dapat diterapkan pada perancangan program ruang, fasad, interior dan yang terpenting adalah lanskap.
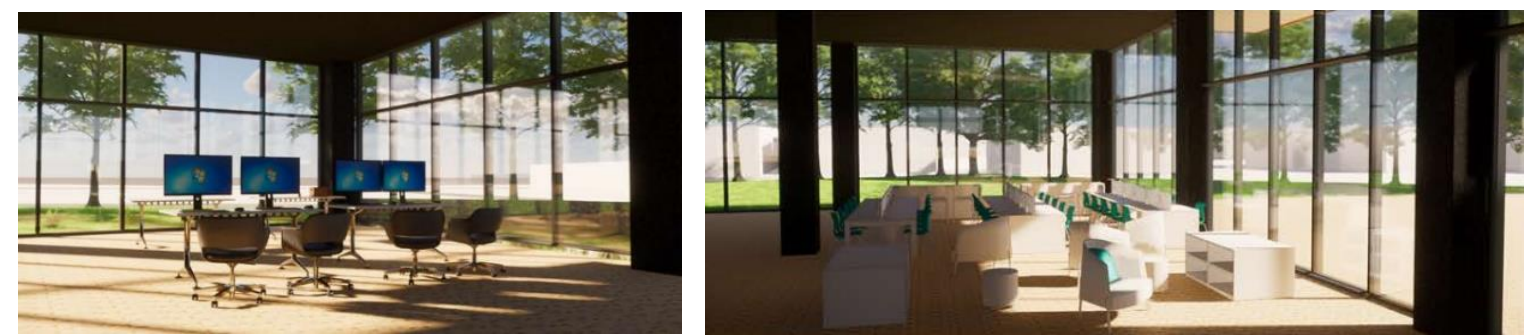

Gambar 2. 6 Perspektif Interior Productive Computer Room \& Library Room sumber : Gambar Rancangan
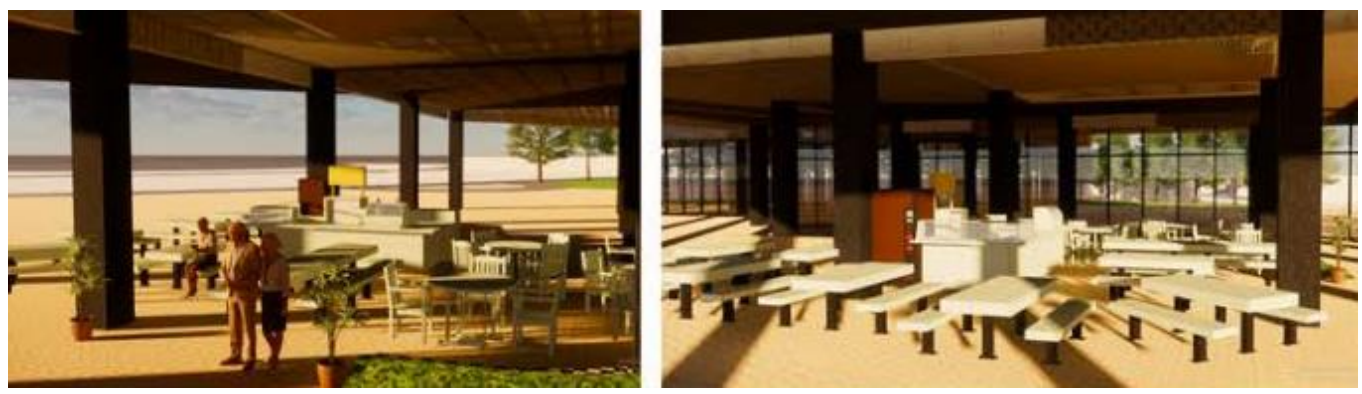

Gambar 2. 5 Perspektif Interior Cafetaria

sumber : Gambar Rancangan

Pada It dasar memuat ruang-ruang yang bersifat publik seperti area produktif yaitu perpustakaan, computer room, cafetaria, community hub, dan pada area layanan kesehatan terdapat ruang konsul, fisioterapi, dan farmasi, sedang pada area day care diarahkan kepada lansia yang datang harian dan tidak menetap dengan fasilitas seperti classroom, playroom, ruang makan bersama, pantry. 

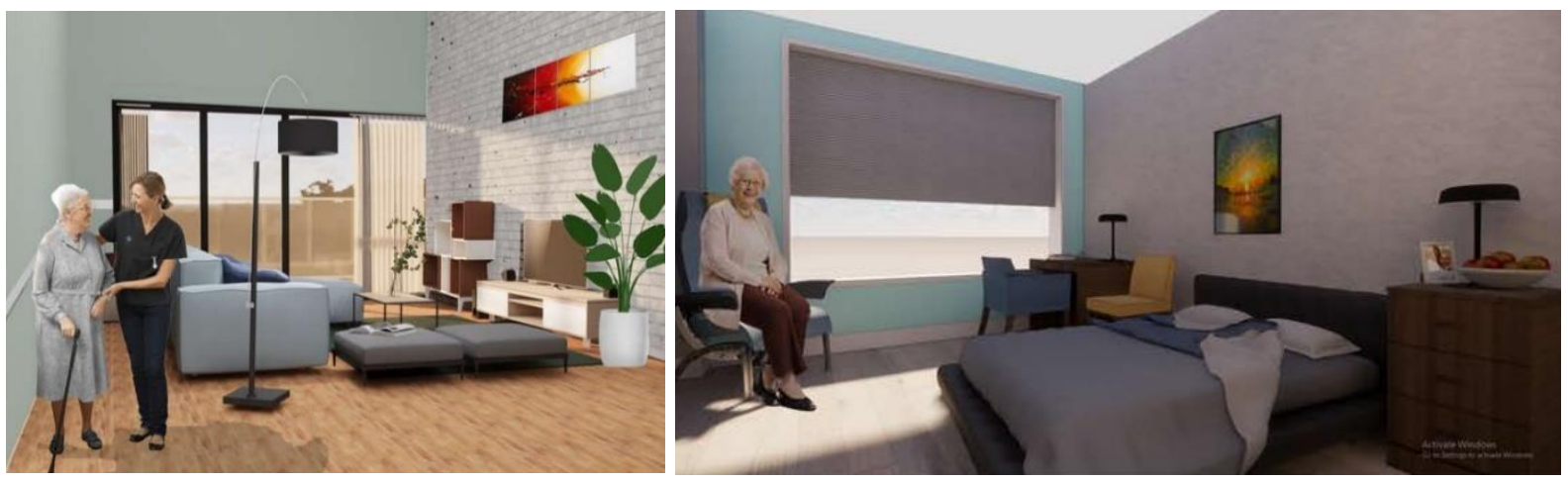

Gambar 2. 7 Perspektif Interior Unit Assisted Living sumber : Gambar Rancangan

Lt2-4 merupakan area hunian yang menerapkan konsep pada program mengakibatkan desain kamar assisted living memisahkan kamar untuk pasien yang memiliki penyakit menular dengan pasien yang tidak memiliki penyakit menular. Terdapat pula ruang transisi untuk mencegah langsung terhadap kemungkinan penularan.

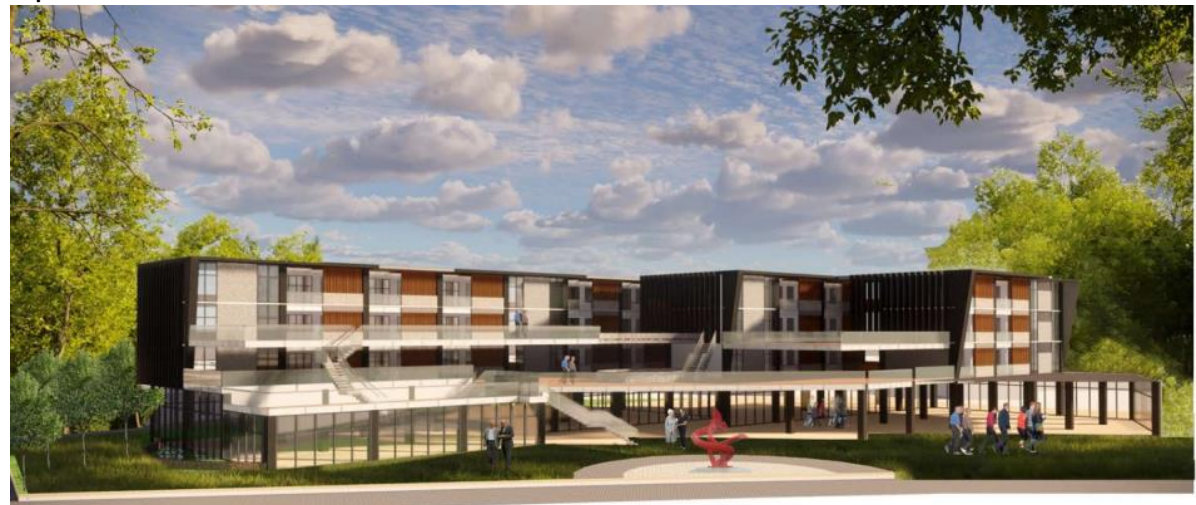

Selain dari program ruang, konsep juga ikut diwujudkan dengan menyediakan aksesibilitas vertikal outdoor dan area area ruang terbuka yang fungsinya fleksibel untuk meningkatkan aktivitas sosial
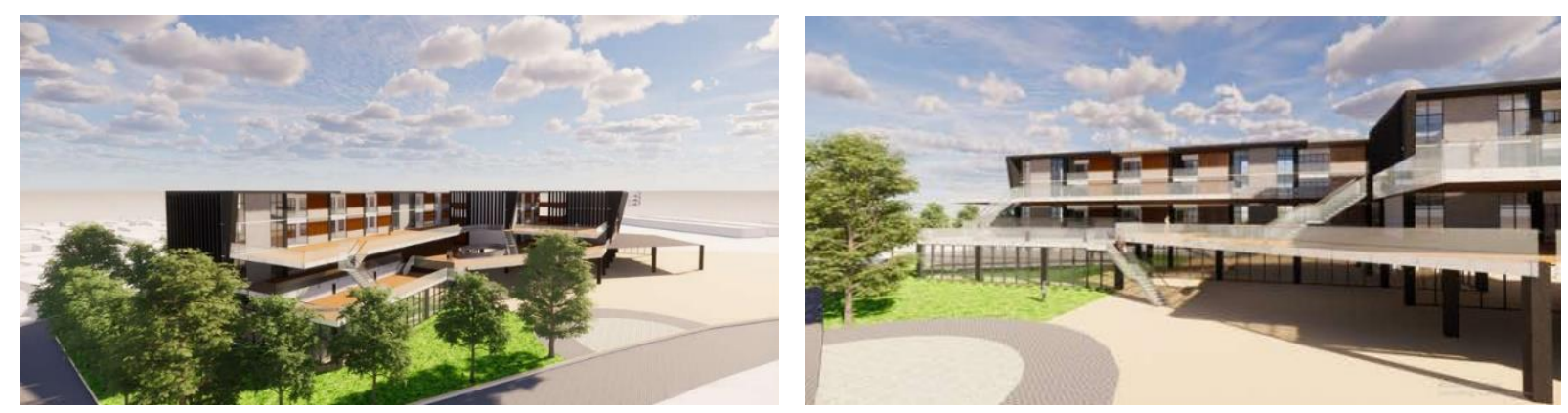

Gambar 2. 8 Perspektif Eksterior

sumber : Gambar Rancangan

lansia pada lantai 2 dan 3, hal ini diharapkan mampu mendorong aktivitas lansia baik secara fisik dan sosial melalui aksesibilitas vertikal yang terpadu dengan area terbuka dan social space.

\section{KESIMPULAN DAN SARAN Kesimpulan}

Rancangan dengan pendekatan therapeutic architecture atau healing environment telah mendorong konsep dan diterapkan melalui program ruang dan secara kontekstual melalui hubungan proyek dengan sekitar bangunan termasuk ruang terbuka hijau. Pemulihan kesehatan seseorang bukan hanya 
didukung secara medis saja, melainkan faktor psikologis juga berpengaruh sebagai faktor pendukung dominan. Masalah penyembuhan seseorang merupakan sebuah kompleksitas yang terjalin antara kesinambungan kondisi fisiologis dan kondisi psikologis (inner mind). Untuk mendukung keduanya, perlu diciptakan lingkungan binaan yang nyaman, dengan artian memberikan lingkungan yang mendukung secara positif penyembuhan di dalamnya. Salah satu contoh dengan mempertimbangkan akses bagi view lingkungan alam atau cahaya matahari untuk masuk ke dalam bangunan. Sehingga arsitektur bukan hanya sebuah lingkungan binaan melainkan jembatan bagi alam dan manusia didalam bangunan yang membutuhkan dosis alam tersebut.

Dalam hal tersebut, bangunan dalam memenuhi kondisi sebagai binaan lingkuangan yang menerapkan healing environment dengan :

a. Tidak Berbahaya : memperhitungkan keamanan bagi user dengan kekokohan, penggunaan bahan dan material, menyediakan suhu udara yang bersih, dan penerangan yang cukup dan aman. Seperti mempertimbangkan mitigasi bencana, jarak lift, dll.

b. Pelayanan Medis difasilitasi : bangunan menyediakan ruang yang efisien dan aman bagi pelayanan kesehatan dengan mempertimbangkan healing environment seperti : memberikan perbedaan ruang bagi penyakit menular, fisioterapi terhubung langsung dengan area taman privat, dll.

c. Berkontribusi pada proses penyembuhan : lingkungan memperhitungkan akses bagi lingkungan serta menyediakan rangsangan yang memadai tanpa memberikan rangsangan yang berlebihan.

\section{Saran}

Terdapat dua elemen dasar yang menyebabkan pengguna lingkungan merespon lingkungannya, stressor dan stress. Stressor adalah elemen lingkungan seperti kebisingan, suhu, kepadatan, dan suasana yang merangsang manusia, sedangkan stress adalah tekanan atau ketegangan jiwa yaitu hubungan antara stressor dengan reaksi yang ditimbulkan. Lingkungan mengandung stimulus atau rangsangan yang kemudian akan direspon oleh manusia. Dalam desain interior lingkungan binaan, semua alat indera dapat dijadikan stimulus, manusia berinteraksi dengan ruang. Beberapa teori membuktikan bahwa dari berbagai macam stimulus yang sudah ada, stimulus visual adalah paling dominan dalam memberikan dampak. Berdasarkan itu, konsep ini dapat didorong lagi dengan pendekatan sensory architecture khususnya pada bidang visual, hal ini khususnya untuk mendorong manusia secara psikologis, baik pada lingkungan binaan kesehatan maupun arsitektur lainnya.

\section{REFERENSI}

Andesty, D, and Fariani S. (2017). "HUBUNGAN INTERAKSI SOSIAL DENGAN KUALITAS HIDUP LANSIA." The Indonesian Journal of Public Health, Vol 13, No 2 Desember 2018: 169-180 -. Accessed June 25, 2021.

Depdikbud. (1995). Kamus Besar Bahasa Indonesia . Jakarta : Balai Pustaka .

Hurlock, B. Elizabeth. (1996). Psikologi Perkembangan, Suatu Pendekatan Rentang Kehidupan. Jakarta: Erlangga.

Maslow, A. (2021). Wikipedia . Februari 13. Accessed Juni 26, 2021.

https://id.wikipedia.org/wiki/Hierarki_kebutuhan_Maslow

Mangoenprasodjo, A. Setiono. (2005). Mengisi Hari Tua dengan Bahagia . Jakarta: Pradipta Publishing .

Notoatmojo, S. (2007). Promosi Kesehatan dan Ilmu Perilaku. Jakarta: Rineka Cipta.

Ramadhani, A. (2015). "Penataan Taman Lansia di Kota Surabaya Berdasarkan Karakteristik Kebutuhan Masyarakan Lansia." Tesis Pada Institut Teknologi Sepuluh Nopember -. Reginer, V. (1994). Assisted Living Housing for The Elderly. New York: Van Noutrand Reinhold. 